\title{
JUSTIÇA RESTAURATIVA: MEDIAÇÃO DE CONFLITO SOCIOAMBIENTAL ENTRE EMPRESA DE PRODUÇÃO DE AÇAI E COMUNIDADES RIBEIRINHAS NA AMAZÔNIA.
}

José Boeing*

Resumo: A violência afeta a toda a comunidade. Daí a necessidade da justiça restaurativa como mediação dos conflitos. Devemos restaurar danos causados nas vítimas. A justiça restaurativa está baseada na ética da alteridade que proporciona o diálogo entre as partes. E poderemos também fazer mediação de conflitos comunitários que envolvem também o meio ambiente. Analisaremos o caso concreto de crime contra os Direitos Humanos e do Meio Ambiente dos pescadores causado pela empresa de produção de açaí no Lago Macupixi, Município de Alenquer, Pará. Práticas restaurativas podem ser implementadas pela sociedade civil com ação extra judicial.

Palavras-chave: Conflito Socioambiental; Mediação; Justiça Restaurativa; Reparar Danos.

\section{INTRODUÇÃO}

A Justiça restaurativa está num processo de afirmação na sociedade. Esta maneira de utilizada para a resolução dos conflitos via mediação e a justiça restaurativa, teve início na Nova Zelândia, Austrália e depois Estados Unidos e Europa a partir de 1970. No Brasil já temos em muitos setores públicos e em organizações da sociedade civil aplicando este método.

A Justiça retributiva quando trata o conflito entre vítima-autor no processo penal tradicional ou clássico, percebe-se a ineficiência do sistema do Estado para solucionar o conflito ou delito causado. A justiça restaurativa vem dando os passos no sentido de valorizar a mediação e as práticas restaurativas nos conflitos interpessoais, familiares, sociais, escolares e ambientais. Historicamente foi construído uma ideia de justiça como castigo, punição para as pessoas que ofenderam ou cometeram crime, violência e danos sociais ou ambientais.

A violência provoca danos e traumas nas vítimas que poderá ser muito difícil de perdoar ao agressor por seus atos. Por isso, a justiça restaurativa tem como primeiro alvo de

\footnotetext{
* Mestre em Direito Ambiental e Desenvolvimento Sustentável da Escola Superior Dom Helder Câmara ESDHC. Doutor em Direito pela Universidad Nacional Mar del Plata, Argentina. Graduado em Filosofia PUC/PR. Bacharel em Teologia pelo ITESP/SP. Graduado em Direito pela FIT/PA. Pós Graduação em Ciências da Religião pelo IESPES/PA. Advogado membro da CPT no Pará e Religioso dos Missionários do Verbo Divino na Amazônia.
} 
cuidado das vítimas. Mas também o autor da agressão deve ser ouvido e acompanhado para refletir sua conduta, ajudando-o a reconhecer o dano causado. E a comunidade também sofre diante das agressões e participar do processo de mediação para alcançar a reconciliação, onde todos ganham. Por isso, a justiça restaurativa condena o delito, mas restaura as pessoas.

O Sociólogo Emile Durkheim, em 1989, escreveu sobre a divisão do trabalho e disse: "Não reprovamos uma coisa porque é um crime, mas é um crime e por isso o reprovamos". Por isso, na sociedade adquirimos os valores morais e éticos para discernir a questão da justiça. A comunidade ou a sociedade está sendo desafiada diante da violência e da opressão econômica, política, reagir a um novo modelo de sociedade baseada nas práticas restaurativas. Neste estudo vamos analisar um caso concreto de conflito socioambiental entre empresa agrícola e pescadores no Pará.

\section{CONCEITO DE JUSTIÇA RESTAURATIVA}

A Justiça Restaurativa vem sendo construída pelos operadores do direito e pelos agentes mediadores de justiça comunitária, social e ambiental, indo além da justiça retributiva. Segundo a United Kingdom: "a justiça restaurativa procura equilibrar o atendimento às necessidades das vítimas e da comunidade com a necessidade de reintegração do agressor à sociedade. Procura dar assistência à recuperação da vítima e permitir que todas as partes participem do processo de justiça de maneira produtiva" (United Kingdom Restorative Justice Consortium, 1998). Esta dimensão de condenar o crime ou delito ou dano nos remete à prática que querer sanar ou reparação este problema. Como afirma Petronella Boonen: "quando acontece um conflito com a lei, um crime, a instituição justiça se volta para o ofensor ou criminoso, tenta mostrar como lesou a sociedade e lhe impõe uma pena. É isso o que comumente entendemos quando afirmamos que 'a justiça foi feita"' (BOONEN,2011).

A Justiça restaurativa com suas práticas restaurativas, por meio de um processo de diálogo entre os envolvidos em conflitos e crimes, podem ser um caminho para a responsabilidade diante do mal causado, superando o trauma e proporcionando uma nova dimensão da relação rompida pela violência ou agressão.

A Fundação para a Reconciliação1 com sede em Bogotá desde o ano 2000, vem desenvolvendo um método de reparação de danos diante da violência. Por isso, criaram as

1 Ver site o trabalho, o método, as áreas de atuação e os países onde já estão presentes. Disponível em: www.fundacionparalareconciliacion.org.br. Acesso em: 26 nov. 2014. 
ESCOLAS DE PERDÃO E RECONCILIAÇÃO - ESPERE como caminho para superar os traumas e violências das vítimas entre pessoas, comunidades e a sociedade. Assim:

\begin{abstract}
Os conceitos comuns que usamos de justiça são os de justiça punitiva (a que castiga) e de justiça restitutiva (aquela onde ocorre a restituição). Com frequência, sentimos falta da justiça restaurativa (a que faz com que as pessoas se recuperem). Estamos dentro de uma cultura que promove a violência e por isso a justiça mais utilizada e que mais exigimos é a justiça punitiva. Respondemos a um mal com outro mal. Um exemplo é que pensamos fazer justiça com a pena de morte e com a prisão perpétua [...]. A justiça restaurativa ou reparadora procura ajudar às vítimas a se libertarem de suas raivas e de seus sentimentos de impotência. Também trata de reintegrar o ofensor novamente à vida da comunidade. Procura que ambos recuperem sua dignidade através de um trato digno. A justiça restaurativa não se esquece da reparação pelo dano causado. Entretanto, muitas vezes é bastante complicado reparar esse dano. Por exemplo, a sequela que deixa a perda de um ente querido, a amputação de uma mão, a lembrança da agonia causada por uma tortura ou a humilhação diante de um sequestro ou uma extorsão. Nesses casos, além da reparação pelo dano causado, muitas vezes é importante fazer uma reparação simbólica (ESPERE, 2011)2
\end{abstract}

A justiça restaurativa tem sua origem muito recente na sociedade como método de mediação e resolução dos conflitos. São experiências que nasceram inicialmente a partir de práticas de diálogo e aplicação de justiça nas culturas dos povos na Nova Zelândia e Canadá em 1970 e depois nos Estados Unidos e Europa. São práticas restaurativas, indo além da justiça punitiva, pois é uma aprendizagem da democracia participativa, pois busca incluir a vítima no processo da reparação do dano causado, fortalecendo os indivíduos e comunidade3.

Este método tem auxiliado em programas sociais no cuidado especial das vítimas, dos lutadores do povo, chamados de defensores da justiça ou melhor os perseguidos por causa da justiça e protege a própria comunidade, encerrando o ciclo de violência, que Olga Botcharova vai chamar de ciclo de dores e emoções da agressão sofrida. Mas não consegue sair da vitimização, reprimindo agora inclusive os sentimentos. A superação do conflito muitas vezes necessita de um terceiro que chamamos de mediação, que a princípio é um método que utiliza a justiça restaurativa na experiência de prática restaurativa com a resolução do conflito.

\footnotetext{
2 Ver sobre o tema das ESPERE - Escolas de Perdão e Reconciliação e sobre a Justiça restaurativa no site da Fundación para la reconciliacón. Disponível em: www.fundacionparalareconciliacion.org/. Acesso em: 24 nov. 2014.

3 Ver sobre o Justiça Restaurativa e Mediação de Conflitos - Mediare. Disponível em: www.mediare.com.br/08artigos_O6justica_restaurativa.html. Acesso em: 23 nov. 2014. Ver também as experiências práticas brasileiras a partir do livro de PRUDENTE, Neemias Moretti. Justiça Restaurativa: Marco teórico, experiências brasileiras, Propostas e Direitos Humanos. Goiânia: Bookess e Kindle, 2013)
} 
No Brasil já se utiliza em muitos lugares a justiça restaurativa em setores públicos, tais como: judiciário, defensoria pública, promotoria de justiça e também nas comunidades escolares, Centros de Direitos Humanos. A prática da justiça restaurativa está no caminho da resolução de conflitos, sendo um novo modelo de justiça voltado para as situações prejudicadas pela existência da violência. Valoriza a autonomia e o diálogo, criando oportunidades para que as pessoas envolvidas no conflito (autor e receptor do fato, familiares e comunidade) possam conversar e entender a causa real do conflito, a fim de restaurar a harmonia e o equilíbrio entre todos. A ética restaurativa é de inclusão e de responsabilidade social e promove o conceito de responsabilidade ativa4.

A prática da justiça restaurativa tem sido constante e a cada experiência de resolução de conflito, existe uma aprendizagem que vai avançando na interação social e a comunidade, percebendo o ganho que se tem com esta prática restaurativa, indo além da justiça punitiva ou retributiva. São muitos os traumas que as vítimas carregam e segundo estudos, $80 \%$ dos agressores hoje, foram vítimas no passado.

A superação ou transformação do conflito deve levar em conta o papel do poder. Alguns tem mais e outros menos. Mas todos têm algum grau de poder. O poder existe sempre em relação a outras pessoas. É fácil abusar do poder quando se nega ou desconhece seu próprio poder. Isto é, alguém age como se tivesse um nível de poder igual ao do outro, e na realidade tem mais poder, por ter mais recursos (materiais, sociais, status, ocupando posições, origem étnica ou de gênero). Esta pessoa sem saber e sem querer ou talvez por interesse pode prejudicar a relação e intimidar o outro. O equilíbrio de poder, entre pessoas e grupos em conflito é muito importante. Pede uma compreensão mais aguda da relação de poder existente entre os envolvidos. Quando a relação é desequilibrada, o acordo é praticamente impossível. Para equilibrar, tem que aumentar de um lado ou/e diminuir do outro lado. Ignorar ou subestimar a importância de balança do poder é ser injusto (LEDERACH, 1997).

4 Ver sobre a Justiça Restaurativa para resolução de conflitos, 2013 . Disponível em:

www.cidadessustentaveis.org.br/...justica-restaurativa-para-resolucao-de-conflitos, 2013.Acesso em: 23 vnov. 2014. Ver também The Virtues of Restorative Processes, the Vices of "Restorative Justice“" (As Virtudes de processos restaurativos, os vícios da "Justiça Restaurativa") de Paul H. Robinson" (Professor de Direito na Pensilvânia). Disponível em: www.restorativejustice.org/articlesdb/articles/3771. Acesso em: 22 nov. 2014. 
A justiça restaurativa está demonstrando nos conflitos pessoais, sociais ou ambientais todos perdem. Mas na resolução do conflito todos ganham, tendo a lógica de perder/perder ou ganhar/ganhar. Segundo, Petronella Boonen da CDHEP - Centro de direitos Humanos e educação Popular de São Paulo, que nos seus estudos e práticas com educadores populares, afirma que necessitamos de práticas restaurativas da vítima, mas também do ofensor que poderá reconhecer o dano causado. Assim, condena-se o crime ou dano, mas restaura as pessoas. Assim ela afirma que no processo de restauração se poder dizer que:

Possibilita à vítima a restauração da integridade moral e física, danificados pelo ofensor; ajuda na reconstrução da sensação de segurança na legalidade; propicia aos ofensores um manejo melhor de sua história, seus atos e suas próprias feridas, desde que assumam o que fizeram; cria espaço, por meio de um diálogo, para as partes adotarem mecanismos de restauração que façam sentido para ambas (BOONEN, 2011, p. 37)

Na Justiça restaurativa se recupera a dignidade da pessoa humana, pois a vítima ganha atenção especial, mas também o ofensor e a comunidade devem participar do processo com ajuda de mediador. Assim o valor sagrado da ação não-violenta, se torna uma realidade como menciona Egberto de Almeida Penido em seu artigo sobre a justiça restaurativa, pois ele percebe três fatores básicos que contribuem para a crise no Direito clássico: “ (a) o predomínio da dogmática do positivismo jurídico; (b) o uso potencial ou efetivo da coação e da violência como forma de composição dos conflitos sociais (o caráter repressivo do Direito, enquanto instrumento de controle social, como apontado por Foucault); e (c) a lógica aplicada na dinâmica e no processo de efetivação da justiça” (PENIDO, 2004 ).

Tânia Almeida, consultora, Docente e Supervisora em Mediação de Conflitos. Sócia Fundadora e Diretora-Presidente do MEDIARE - Diálogos e Processos Decisórios. Analisa no artigo que apresenta os caminhos práticos da justiça restaurativa e defende o diálogo no processo decisório na mediação dos conflitos e na gestão de política restaurativa como programa. Ela coloca as dimensões que pode ser utilizado a mediação, tais como:

Conferências familiares - Esse processo é especialmente utilizado quando se deseja dar foco ao suporte que familiares, amigos e outros membros da comunidade podem oferecer ao ofensor, tanto no cumprimento de condutas acordadas com a vítima e com a comunidade, como na mudança de seu comportamento. Representantes do estado podem estar presentes nesse processo de diálogo facilitado por um terceiro imparcial que deverá conduzilo de maneira a balancear o atendimento das necessidades de ambas as partes, ofensor e vítima.

Círculos de Construção de Consenso - Inspirados em comunidades indígenas, esses círculos de conversa e de construção de consenso envolvem um número maior de pessoas - vítimas, ofensores, seus familiares, a comunidade e os operadores do Direito. Os círculos incluem a presença do juiz e a construção 
consensual da sentença para o delito. A utilização desses círculos de construção e monitoramento de observâncias transcende hoje o seu emprego a questões relativas a delitos. Estes círculos vêm sendo utilizados em processos de diálogo que envolvem construção de consenso em questões comunitárias e institucionais (ALMEIDA, 1999).

Há ainda muitas divergências quando se trata do assunto Justiça restaurativa nos fundamentos. No entanto, está ganhando força no sentido dos seus valores, processos e seus resultados obtidos, quando praticados dentro da coletividade, procurando envolver todos os diretamente afetados pelo conflito.

\title{
3. MEDIAÇÃO DE CONFLITOS COMO CAMINHO PARA A JUSTIÇA RESTAURATIVA
}

A partir de 2002 com o incentivo da ONU, pensando saída para a justiça em forma de restauração da vida e das pessoas, indo além da punição, no Brasil desenvolveu um processo de experiências neste campo sócio, econômico e ambiental. Segundo Karina Duarte Rocha Silva, faz uma análise da justiça restaurativa e sua aplicação no Brasil, citando a decisão das Organização das Nações Unidas - ONU -em 2002, quando definem Justiça Restaurativa numa visão de superação do conflito, afirmando que:

\begin{abstract}
A Justiça Restaurativa refere-se ao processo de resolução do crime focando em uma nova interpretação do dano causado às vítimas, considerando os ofensores responsáveis por suas ações e, ademais, engajando a comunidade na resolução desse conflito. A participação das partes é uma parte essencial do processo que enfatiza a construção do relacionamento, a reconciliação e o desenvolvimento de acordos concernentes a um resultado almejado entre vítima e ofensor. (...) Através deles, a vítima, o ofensor e a comunidade recuperam controle sobre o processo. Além disso, o processo em si pode, frequentemente, transformar o relacionamento entre a comunidade e o sistema de justiça como um todo. [Nossa livre tradução (SILVA, 2007, p. $24) 5$.
\end{abstract}

\begin{abstract}
5 No original: "Restorative justice refers to a process for resolving crime by focusing on redressing the harm done to the victims, holding offenders accountable for their actions and, often also, engaging the community in the resolution of that conflict. Participation of the parties is an essential part of the process that emphasizes relationship building, reconciliation and the development of agreements around a desired outcome between victims and offender. (...) Through them, the victim, the offender and the community regain some control over the process. Furthermore, the process itself can often transform the relationships between the community and the justice system as a whole". (UNITED NATIONS. Office on Drugs and Crimes. Handbook of Restorative Justice Programmes. Criminal Justice Handbooks Series. Disponível em http://www.idcb.org.br/documentos/Ebook_justice.pdf. Acesso em 10 de julho de 2007. p. 06.). Apud SILVA, Karina, 2007, p. 24).
\end{abstract}


Em 2005 o Ministério da Justiça e PNUD apoiou 3 projetos: Porto Alegre, São Caetano do Sul e Brasília, com o tema; "Promovendo Práticas Restaurativas no Sistema de Justiça Brasileiro", conhecido depois como Projeto "Justiça para o Século 21" (PNUD/MINISTÉRIODA JUSTIÇA, 2013). Este projeto ganhou ênfase, depois exatamente de Porto Alegre ter sediado em 2001, 2003 e 2005, o Fórum Social Mundial - FSM que reuniu milhares de pessoas e entidades, trazendo suas iniciativas de que um "outro mundo é possível".

Segundo o trabalho da equipe de capacitação da justiça em círculo, coordenada por Vânia Curi Yazbek, que apresenta a justiça restaurativa como um método de resolução de conflitos e se fundamentam no princípio do processo da mediação e justiça restaurativa com principais semelhanças, conforme Christopher Moore já em 1985 entendia: "Lidam com o diálogo como ferramenta; há um mediador ou facilitador do diálogo; resultado em poder das partes; processo voluntário cooperativo; aprendizado para lidar com os conflitos futuros; horizontalidade; inclusão e voz a todos e conotação positiva do conflito"(YAZBEK, 2007).

Daí podemos garantir que a mediação e justiça restaurativa tem muitos pontos que se complementam, reforçando os valores do empoderamento, participação, autonomia, respeito, responsabilidade pelos danos causados. Esta educação a partir dos Direitos Humanos para uma cultura da paz, utilizando a mediação se dá na vontade de superar o conflito para viver em harmonia na construção de uma vida comunitária.

\footnotetext{
Os sentidos da Mediação de conflitos. Nesse contexto de educação em direitos humanos e de promoção de uma cultura de paz, destacamos a importância da Mediação de Conflitos como dispositivo imprescindível nos mais diversos espaços educativos. Mais do que uma metodologia de intervenção em intervenção em situações de conflitos de gênero, sexuais, raciais, sócio-econômicos e outros, apontamos a mediação de conflitos como um estilo de vida do/a educador/a nesses espaços educativos formais e nãoformais (ASSIS, 2014)6.
}

O valor da dignidade da pessoa humana como está garantido nos direitos fundamentais, nos assegura que a justiça é a base dessa dignidade, pois todos têm direito de ser respeitados, protegidos e ao mesmo tempo promotores da justiça e da paz.

6 Ver sobre o tema uma Coletânea de artigos elaborada pelo Projeto Integrando Ações de Educação em Direitos Humanos em Minas Gerais: uma parceria entre FMDH e UFMG. Órgão Fomentador: SEDH-Governo Federal Disponível em: http://www.direito.ufmg.br/edhmg/livro_eletronico/livro_eletronico.pdf.Acesso em; 22 nov. 2014. Para maior aprofundamento sobre Mediação de Conflitos, remeto ao leitor o site http://www.gentequefazapaz.org.br, com cartilha sobre mediação e outros recursos promotores da paz; 


\section{ESTUDO DE CASO: EMPRESA DE PRODUÇÃO DE AÇAÍ NO PARÁ, DESRESPEITA OS DIREITOS HUMANOS DOS PESCADORES E CAUSA DANOS AMBIENTAIS NO LAGO MACUPIXI EM ALENQUER, PARÁ.}

Quando falamos de justiça restaurativa, estamos partindo da realidade concreta, onde os conflitos são reais e provoca na comunidade uma tensão devido os interesses que estão em jogo. Entendendo que a Justiça Restaurativa tem como objetivo primeiro, o cuidado com a vítima que pode ser uma pessoa, grupos comunitários ou o próprio Meio Ambiente. O caso de vamos conhecer e analisar é o caso concreto da empresa agrícola Polpas da Amazônia que se instala no Município de Alenquer, estado do Pará com o projeto de plantio de 600 hectares de açaí. Todos sabemos que o açaí necessita de muita água por ser de clima tropical. No entanto, a instalação do projeto solicitou à SEMA Municipal a autorização de realizar uma barragem no Igarapé de Canacupá, represando as águas do lago Macupixi. Esta autorização concedida pela autoridade afetou diretamente os pescadores e a vida das comunidades no entorno do lago e dos igarapés vizinhos. Com a barragem montada, a balsa flutuante com motor para captação de água do lago e a destruição das APPs fez os comunitários, através de suas entidades representativa agirem, solicitando a intervenção do Ministério Público e da SEMA estadual, IBAMA e Poder público Municipal de Alenquer. Vamos conhecer o caso desde 2010 e como está a situação e os caminhos percorridos para se chegar por via de negociação e mediação do conflito.

\subsection{Histórico do conflito socioambiental}

O Sindicato dos Trabalhadores e Trabalhadoras - STTR, de Alenquer, PA, Colônia de Pescadores Z-28 de Alenquer - PA, Associação dos Negros do Quilombo do Pacoval de Alenquer - ACONQUIPAL, Comissão Verbita, Justiça, Paz e Integridade da Criação -JUPIC de Alenquer, PA, Instituto da Nova Amazônia de Cidadania, Cultura e Desenvolvimento Sustentável de Alenquer, PA, Comissão Pastoral da Terra - CPT, Óbidos, PA e Paróquia Santo Antônio de Alenquer, PA, ofereceram uma denúncia junto ao Ministério Público Estadual na Comarca de Alenquer em nome de 800 famílias de agricultores e pescadores de Alenquer contra a Empresa agrícola Polpas da Amazônia por violação aos Direitos Humanos e danos ambientais.

As 800 famílias de agricultores e pescadores da região foram afetadas pelo empreendimento de plantação de Açaí na beira dos Igarapés e com o fechamento da 
barragem. Os comunitários e entidades representativas fizeram uma vistoria na região no dia 20 de outubro de 2010, e constataram os danos ambientais e sociais na região. Esta vistoria foi acompanhada pelo técnico Cleiso da ouvidoria agrária do INCRA de Santarém, Pará, no local do igarapé Canacupá, Ingá. Marajá e Macupixi e entorno.

O objetivo das entidades entrarem com o pedido de audiência ao MP Estadual, foi no sentido de preservar as águas dos igarapés que são afluentes do Rio Curuá, pois a barragem afeta diretamente as 14 comunidades de agricultores e pescadores. A construção da barragem no igarapé Canacupá realizada pela Empresa Polpa da Amazônia do Grupo Vaccaro com sede no Município de Óbidos, estado do Pará com a finalidade de irrigar a plantação de Açaí, prejudicará toda a vida dos moradores. Além da balsa flutuante com motor de captação de água do Lago Macupixi e a destruição das APPs.

No dia 01 de Novembro de 2010, as entidades realizaram um amplo relatório de toda a situação e afirmaram que desde 2008 a empresa vem agindo na região, fazendo desmatamento na beira dos Igarapés e realizam reuniões nas comunidades, afirmando que tem autorização da SEMA municipal de Alenquer para desenvolver o projeto de plantio de açaí. Já ocorreu desmatamento e o fechamento do igarapé com a barragem. Este documento foi direcionado ao Ministério Público Estadual e protocolado no dia 03 de Novembro de 2010, com anexos do documento do parecer do Técnico do INCRA, os registros com fotos e depoimentos dos moradores, da ata da Assembleia realizada com os comunitários e a lista de presença. As reivindicações ao MP estadual foram as seguintes:

Que O MP solicite à SEMA Estadual informações sofre o devido projeto da
empresa Polpa da Amazônia do grupo VACCARO se tem autorização para o
devido empreendimento; que o IBAMA seja notificado pra saber se o
EIA/Rima foi realizado; Que a SEMA municipal dê esclarecimento se o deu
autorização para o empreendimento; Que o MP de Óbidos informe sobre a
legalidade e representatividade da entidade jurídica, tendo como
representante o SR. Eloy Luiz Vaccaro; Que realizadas audiências públicas
nas comunidades afetadas pelo empreendimento, coordenada pelo MP
estadual; que seja feita uma vistoria para verificar os danos ambientais com a
barragem(STTR - ALENQUER, 2010).

Que no dia 16 de Novembro de 2010, as entidades, protocolam o documento o Ministério Público estadual em Alenquer, Pará, com fundamentado no artigo $5^{\circ}, \mathrm{XXXIV}$, alínea 'a" as entidades fazem uma REPRESENTAÇÃO POR CRIME AMBIENTAL C/C PEDIDO DE INTERVENÇÃO MINISTERIAL JUNTO AO JUDICIÁRIO EM SEDE DE MEIDDA CAUTELAR PREPARATÓRIA DE AÇÃO CIVIL PÚBLICA, com fundamento na Lei Processual Civil e na Lei de Ação Civil Pública, em face de Eloy Luiz Vaccaro, 
representante da Empresa Polpa da Amazônia do Grupo Vaccaro, podendo ser notificado na sede da empresa na cidade de Óbidos, estado do Pará. Os motivos são os crimes ambientais, conforme art. 54, da Lei 9.605/98:

Causar poluição de qualquer natureza e níveis tais que resultem ou possam resultar em danos à saúde humana, ou que provoquem a mortandade de animais ou a destruição significativa da flora: Pena - reclusão, de um a quatro anos, e multa. Também o artigo 60 da mesma lei que diz- Construir, reformar, ampliar, instalar ou fazer funcionar em qualquer parte do território nacional, estabelecimentos, obras ou serviços potencialmente poluidores, sem licença ou autorização dos órgãos ambientais competentes, ou contrariando as normas legais e regulamentares pertinentes: Pena - detenção, de um a seis meses, ou multa, ou ambas as penas cumulativamente.

Sobre a violação do código Florestal as entidades alegaram as seguintes violações, fundamentados no art. $3^{\circ}$ da Lei 4.771/65:

Consideram-se, ainda, de preservação permanentes, quando assim declaradas pro ato do Poder Público, as florestas e demais formas de vegetação natural destinadas: a) atenuar a erosão das terras; (matas ciliares). E o art. $4^{\circ}$ da mesma lei que diz - A supressão de vegetação em área de preservação permanente somente poderá se autorizada em caso de utilidade pública ou de interesse social, devidamente caracterizados e motivados em procedimento administrativo próprio, quando inexistir alternativa técnica e locacional ao empreendimento proposto (Medida Provisória n. 2.166-67, de 2001);

Diante dos argumentos legais as entidades em nome das comunidade afetadas solicitarama condenação dos responsáveis com as sançoes penais, administrativas e civis, solitando que os órgãos responsáveis do Meio ambiente façam a vistoria pra aplicar as sanções de acordo ao crime ambiental. E por fim, que seja concedida a medida cautelar para evitar maiores danos ambientais e a suspensão ou embargo da construção da barragem destinado a reservatório artificial com reparação imediata do dano ambiental, retirando todo material da cosntrução da barragem liberando a água para que os peixes possam fazer a piracema.

A população, percebeu que a empresa continua o projeto de plantio do Açaí, inclusive de ampliação para chegar aos 600 hectares nos próximos anos. Por isso, vendo que as Leis Ambientais não estão sendo respeitadas, as mesmas entidades em defesa das famílias afetadas, no dia 02 de dezembro de 2010, protocolaram sob o número 150/2010, um documento no Ministério Público Estadual na Comarca de Alenquer, estado do Pará, denunciando o crime ambiental executado no igarapé Canacupá e Lago Macupixi e entorno, solicitando uma audiência pública para buscar uma solução para o conflito socioambiental. Documentação ao MPE- 12/04/2011 protocolo $n^{\circ}$ 080/2011 da reunião na fazenda em 
26/04/2011com MPE, SEMA Municipal, Engenheiro do MPE, entidades e representantes comunitários:

\begin{abstract}
a)que seja encaminhado cópia do relatório técnico produzido pelo técnico especializado do Ministério Público; b) Que seja realizada audiência pública no Ginásio Poliesportivo de Alenquer, onde seja garantida a participação das comunidades que direta e indiretamente já estão afetadas pelo referido, bem como de outras comunidades que tenham interesse em discutir o projeto em questão, uma vez que há possibilidade de interferir em várias atividades do Município de Alenquer; c) Que seja encaminhado RECOMENDAÇÃO ao responsável pelo empreendimento do GRUPO VACCARO para que seja paralisada qualquer obra ou serviço pertinente à construção da barragem, enquanto perdurar as discussões com as comunidades afetadas todos (STTR ALENQUER, 2011).
\end{abstract}

Após esperar por muitos meses a próxima reunião com o promotor e uma decisão que não chegou, os comunitários resolveram mostrar sua força de organização e união. Os mesmos resolveram retirar a barragem, mas devido muito entulho o objetivo não foi alcançado, retiraram só uma parte da mesma. Na reunião das comunidades afetadas pelo empreendimento de produção de Açaí que necessitando de água, o Grupo Vaccaro, fez uma barragem no Igarapé sem estudo de e impacto ambiental ou consulta às comunidades, prejudicando o ciclo da piracema e afetando economicamente as 800 famílias que vivem na região da terra e do peixe. Por isso, as entidades convocaram todos os moradores das comunidades da região, realizando a assembleia e ficou decidido:

\begin{abstract}
Na reunião das comunidades afetadas Pacoval, Boqueirão, Canacupá, Praia Grande, arrelia, Quintiliano, Vila de Palha, Nova Esperança, Travessão, Novo Progresso I, Novo Progresso II, Macupixi, Nova Olinda, Santa Marta, Mediã, Caitittu, São Miguel, Goiana Grande, Goianinha, Patauá, Ajará e Ingá: "decidiu-se a retirada da Barragem do igarapé de Canacupá porque esse projeto de Polpa do Baixo Amazonas é um projeto pelo poder e dos líderes da sociedade em nome do Desenvolvimento Sustentável? Pode a MONOCULTURA trazer benefícios par a maioria da sociedade? A maioria visa que esse projeto PBA não é beneficente e em especial a Barragem. Por isso, decidiu-se em retirar a barragem na ação organizados pelas entidades sociais e comunidades e a população em geral no dia 30 de setembro de 2001. Como " uma só formiga não dá conta da roseira, mas desfolha a mata se juntar ao formigueiro". E "apesar de sermos muitos só seremos fortes se nos unirmos". Estamos unidos na luta pela vida em abundância para todos (STTR ALENQUER, 2011).
\end{abstract}

Na madrugada do dia 23/10/2011, a empresa Polpa da Amazônia, através de seus funcionários da fazenda, utilizando máquinas voltam a aterrar o igarapé sem piedade, impedindo a passagem de água e dos peixes. Além de fazerem novamente a barragem com pedras e terra, os Gerente Cristiano Vaccaro, através de seus advogados, fizeram o Boletim de 
Ocorrência acusando os comunitários e nominado os líderes das entidades como responsáveis pelo dano ao patrimônio. Consequências desta ação foi o Boletim de Ocorrência do Gerente da empresa contra os líderes que foram intimados: João Gomes presidente, Izaías Batista vice presidente e Aldemara secretária da mulher do STTR, Pe. Siluvay, e os comunitários Laércio do Ingá, Raimundo do Macupixi e Paulo Barba.

Esta situação causou uma polêmica na cidade e nos órgãos públicos e nas entidades. E começou a questionar nas escolas e no meio de comunicação. Quem são os Direitos Humanos e do Meio ambiente? A empresa que viola o direito de vida econômica das comunidades, como a anuência da SEMA Municipal que realiza a barragem no Igarapé Canacupá afetando o meio ambiente ou os comunitários que retiram a barragem para salvar a água e os peixes? Os comunitários alegaram na delegacia, através de seus advogados Dr. Dilton Tapajós e Dr. José Boeing a necessidade de salvar as espécies de peixes que servem de alimento para as famílias.

No dia 26 de outubro de 2011, as entidades, representantes dos trabalhadores e pescadores, encaminham denúncia ao INCRA, IBAMA, MPE, SEMA municipal e estadual e questionam o gerente da empresa Sr. Cristiano Vaccaro, sobre o acontecido o mesmo diz que não estava sabendo sobre o aterro. No entanto, os documentos apresentaram os argumentos do impasse e conflitos ao crime ambiental, ressaltando que:

\begin{abstract}
o inquérito civil $\mathrm{n}$. que se desenvolve nesse promotoria em desfavor da empresa POLPAS DO BAIXO AMAZONAS INDÚSTRIA E COMÉRCIO Ltda.(GRPO VACCARO - POLPA DA AMAZÔNIA), com objetivo de apuar denúncia de degradação ao meio ambiente e construção irregular de barragem e considerando, em especial, a RECOMENDAÇÃO N. 005/2011MP/1 ${ }^{\circ}$ PJA, em que RECOMENDA a atualização do Plano de Controle Ambiental do empreendimento sob reponsabilidade da empresa polpas do Baixo Amazonas, elencando objetivamente as seguintes exigências: (1) controle de resíduos decorrentes do uso de herbicidas; (2) proteção odos peixes; (3)monitoramento do controle das águas; (4) proteção da migração dos peixes no entorno do barramento; (5) estabelecimento de estratégias de comunicação social do projeto com a comunidade diretamente afetada visando a informação e o detalhamento de todas as fases do empreendimento; (6) discussão de outras alternativas de aproveitamento de águas para irrigação no período de estiagem. Demonstrando a vantagem do barramento em detrimento de outras alternativas (STTR - ALENQUER, 2011)
\end{abstract}

No documento encaminhado ao Promotor Público da Comarca de Alenquer neste mesmo dia 26 de outubro de 2011, ficou claro o interesse das comunidades, através das entidades em não abrir do direito de viver dignamente na região, não aceitando a barragem. No entanto está aberto ao diálogo no sentido de encontrar a melhor solução ou alternativas 
viáveis para solução do conflito, contentando ambas partes. Por isso, solicitam do promotor uma atuação, pois:

\begin{abstract}
A empresa autuada extrapolou todas as formas autoritárias e desrespeitosas que vinha até então utilizando para conseguir seu intento, pois essa empresa tomou ciência das recomendações emanadas dessa promotoria, por meio do Ofício n. 296/2011 - MP/1 ${ }^{\mathrm{a}} \mathrm{PJA}$, de 07/10/2011, onde ciente do gerente administrativo da empresa autuada, Sr. Cristiano Peruzzo Vaccaro. Portanto, essa pessoa foi processualmente cientificada para DISCUTIR OUTRAS ALTERNATIVAS DE APROVEITAMENTO DE ÁGUAS PARA SEU EMPREENDIMENTO, bem como de que DEVERIA DEMONSTRAR A VANTAGEM DO BARRAMENTO, assim como A PROTEÇÃO DOS PEIXES, O CONTROLE DA QUALIDADE DAS ÁGUAS, A PROTEÇÃO DA MIGRAÇÃO DO SPEIXES NO ENTORNO DO BARRAMENTO. Nada disso a empresa autuada considerou. O desrespeito é patente. De forma deliberada, abusiva, afrontada às autoridades constituídas e com desrespeito às famílias que há décadas utilizam aquele igarapé, de todos os modos, para suas sobrevivências, sem nunca o ter poluído, nem sequer modificado sua coloração, procedeu como se mais nada interessasse a ela (empresa autuada) a não ser o seu próprio lucro (STTR - ALENQUER, 2011).
\end{abstract}

O documento solicitando a intervenção ou mediação do Ministério Público Estadual tem uma importância, pois as entidades solicitam um mediador, pois não se opõe ao empreendimento de produção de Açaí que culturalmente é muito importante para Amazônia. Mas como o empresário é do sul do Brasil, pensa em obter lucro fácil sem cumprir a legislação e muito menos respeitar a vida dos moradores da região que dependem da água "livre" sem barragem para a piracema e a pesca. Diante desse impasse, as entidades e as comunidades seguiram suas lutas e organizações. Por isso, no dia 30/11/2011, realizou-se no quilombo pacoval uma grande assembleia com representes de todas as comunidades direta e indiretamente afetas, que levantaram as seguintes preocupações:

\footnotetext{
Dezembro e janeiro é o período da desova/produção dos peixes, quando eles sobem para reproduzir, sendo que o barramento afetará esse ciclo natural; que agentes da empresa disseram que irão colocar muitos alevinos no Lago Macupixi, sem qualquer preocupação sobre que espécie; que já houve muita morte de peixes, por causa do representante do Igarapé; que estão muito preocupados, por causa do veneno que é colocado no plantio do açaí; que a empresa mantêm uma BALSA FLUTUANTE no lago Macupixi, como motor potente, retirando águas do Lago 24 horas por dia, para irrigar o açaizal.(STTR - ALENQUER, 2011).
}

Com objetivo de encontrar a solução do problema de forma mansa e pacífica, foi deliberado, pedindo apoio dos 2 Vereadores presente nesta assembleia de Pacoval para solicitar uma Sessão Especial ao Poder Legislativo Municipal, com o objetivo da intervenção do poder público no processo de mediação para solução do conflito ambiental. 


\subsection{Resistência das Comunidades em defesa do Meio Ambiente}

Este conflito pode-se estudado pela via da resistência e o empoderamento que as comunidades adquiriram com o apoio das entidades de assessoria, advogados e Ministério Público. Chamamos isso de resistência e perseverança das lideranças de sempre buscar a justiça com não-violência. Se por um lado, a empresa com projeto de produção de Açaí com tecnologia melhor e mais rápida de produção e abastecimento da região e do país. Este fato não se questiona, pois é uma geração de renda e desenvolvimento local. No entanto, não se pode desenvolver a região com uso de 600 hectares de terra de produção de açaí, se ao necessitar de água para irrigação se faz uma barragem no igarapé, prejudicando 800 famílias que vivem dos peixes e das águas, instalando uma balsa flutuante com motor de captação de águas e destruição das APPs. Como fazer a mediação desse conflito, garantindo os 3 pilares do Desenvolvimento Sustentável: a economia, o social e o ambiental?

Qual será a solução deste conflito? Poderemos encontrar saída, apenas acionando o Ministério Público, os órgãos ambientais municipal e estadual? Será possível obter uma decisão judicial satisfatória para o conflito? Que medida adotar? Quem poderá mediar este conflito?

Audiência na Câmara Municipal de Alenquer, Pará no 06/12/2011 com Entidades, Comunidades afetadas, Empresa, SEMA de Alenquer e Vereadores. Não chegando num consenso sobre o problema da barragem, do desmatamento da APP, do período da piracema, afetando os peixes e trazendo prejuízo econômico para as famílias das comunidades, foi proposto novo encontro para o dia 17/01/2012, na Câmara Municipal de Alenquer, tendo como pauta a busca de solução diante do conflito, embora a questão da barragem deve ser retirada. O que fez pensa é encontrar outras alternativas viáveis para a captação de água para irrigação do açaizal.

Nesta perspectiva aconteceu o encontro entre as partes no dia 17 de Janeiro de 2012 com os seguintes participantes: Representantes dos Vereadores, Cristiano do Grupo Vaccaro; Dr. Nonato, Advogado da empresa, Rejane, engenheira florestal da empresa; secretário da SEMA Municipal, os representantes das entidades e comunidades: Célio, João Gomes, Aldemara, Izaías e Manuel Israel. E Dr. Dilton, advogado das entidades. Vale ressaltar que vários comunitários acompanharam a discussão sem direito a voz e inúmeras pessoas no lado de fora da Câmara, aguardava a decisão do encontro. Os encaminhamentos foram: 
Até o dia 24 de janeiro de 2012, a empresa comunicará oficialmente à SEMA municipal que retirará a barragem depois de um estudo da engenheira da empresa para estabelecer o plano de ação que desenvolverá na região. A retirada total da barragem ficou o prazo até 30 de novembro de 2012, com a retirada do entulhos, pedras e terra no local da barragem. Também a empresa se compromete a fazer um estudo de encontrar uma alternativa de retirada do motor e balsa flutuante, pois mesmo sem a barragem a captação de água permanente, prejudicará o lago e os peixes no período dos 6 meses de estiagem que vai de julho a dezembro de cada ano. Também o compromisso da empresa de recuperar a APP ao longo do lago e igarapé afetados. Quanto ao futuro da região e preservação do meio ambiente será criado o comitê da bacia do Lago do Macupixi para atuar permanentemente em defesa das águas e do meio ambiente (STTR - ALENQUER, 2012).

No final do encontro de mediação do conflito, fez-se uma avaliação por parte dos comunitários e entidades que durante 2 anos buscaram junto ao poder público SEMA estadual, Municipal e vereadores com o Ministério Público estadual a solução do conflito socioambiental. Avaliaram como um tempo de luta, coragem, organização, disponibilidade, união das comunidades, conquista, apoio de outras comunidades, valorização da organização e apoio das entidades.

No dia 17 de janeiro de 2013, exatamente um ano após o encontro de mediação e acordo do conflito, houve o novo encontro para avaliar o cumprimento ou não do acordo. Chegou-se a constar que a barragem não foi retirada juntamente com o motor no Lago Macupixi. O gerente da empresa Polpas da Amazônia, Cristiano Vaccaro fez suas justificativas pelo não cumprimento do acordo. No entanto, as comunidades exigiram uma solução, ficando acertado para o dia 24/01/2013, o trabalho de retirada da barragem com a presença e acompanhamento das comunidades. Podemos afirmar que este trabalho foi realizado e no dia marcado, deu-se início dos trabalhos de retirada definitiva do barramento com o acompanhamento dos comunitários, garantindo assim a solução do conflito e esperança de dias melhores para as presentes e futuras gerações daquela região.

\subsection{Responsabilidade jurídica diante dos danos ambientais}

Analisando o caso da barragem do Lago Macupixi no Município de Alenquer, estado do Pará, não foi fácil convencer à empresa de sua responsabilidade nos danos ambientais. Por fim foi firmado o acordo. Mas se tratando de futuramente avaliar a execução, temos a dificuldade de fazer que os órgãos públicos e ambientais acompanhem todo o desenvolvimento das medidas reparadora. Para ilustrar melhor esta situação, depois de ter sido feito a avaliação um ano depois do acordo. Isto é, em Janeiro de 2013, percebeu-se que 
nem tudo foi realizado. Mas na avaliação e novo acordo, deu-se por garantir a execução do planejado e acordado.

No dia 24 de novembro de 2014, passado quase 2 anos do último acordo, foi encaminhado umas questões de avaliação de como está a situação do empreendimento agrícola de plantio de Açaí e a vida das comunidades no entorno do Lago Macupixi. Entrevistamos João Gomes, presidente e Aldemara Ferreira, secretária do STTR- sindicato dos Trabalhadores e Trabalhadoras rurais de Alenquer, estado do Pará. As questões foram respondidas assim:

1.Você acha que a luta pela mediação do conflito de fazer o acordo de não ter a barragem, garantiu a vida melhor para as famílias da região? A resposta foi: "sim pois garante a liberdade dos comunitários, e a reprodução de peixe nos lagos e igarapés que sustenta os de geração em geração"; Os acordos foram cumpridos? Resposta: "Foram cumpridos em parte, foi tirado parte dos materiais depositados no leito do igarapé Canacupá não foi feito a recuperação das APPs que a empresa se comprometeu e nem foi tirado os motores do lago"; 3. Como você avalia esta luta em defesa da terra e do meio ambiente para o povo de Alenquer? Reposta: "Muito positiva e necessário pois a atuação do STTR, PARÓQUIA, JUPIC e outras entidades e a defesa dos advogados(as) Dr. Pe. Boeing, Dr. Dilton, Dra. Rafaela e Dr. Regiane, tem sido muito importante nas lutas do povo"; 4. Que experiência vocês tiveram dessa luta? Resposta: "Que a união faz a força não só a união dos trabalhadores mais também das entidades e dos advogados e que precisamos ser persistentes porque nem sempre podemos contar com todos que poderiam nos ajudar, pois fizemos várias denúncias ao MPE ao IBAMA e a SEMA e não deram respostas em favor do nosso território". Como vocês veem a responsabilidade jurídica da empresa no desenvolvimento regional na questão econômica, social e ambiental? resposta: "agora a fase de implantação do projeto tipo os serviços braçal estar terminado, as pessoas que estavam empregadas já estão ficando desempregadas, a empresa não paga impostos em Alenquer pois a indústria fica em Obidos, a empresa tenta enganar as pessoas de algumas comunidades (ALENQUER, 2014)7.

7 A entrevista foi realizada via e-mail que foi enviado as perguntas e foi respondida e devolvida a partir dos documentos que o STTR de Alenquer tem se seus arquivos e que forneceram para fazer este estudo e análise dos avanços e impasses da mediação socioambiental em Alenquer, Pará. 


\section{JUSTIÇA RESTAURATIVA E AS MEDIDAS DESPENALIZADORAS DE DIREITO AMBIENTAL}

A justiça restaurativa e as medidas despenalizadoras de Direito Ambiental nos faz refletir sobre a necessidade de encontrar caminhos de responsabilidade civil e penal para os danos ambientais. Eles podem ter sido causados por pessoas físicas ou jurídicas. Mas como fazer a reparação dos danos, a partir da compreensão que o autor que devem reconhecer que causou o dano. Esther Giménez-Salinas i Colomer fala que não há um único objetivo de mediação, mas que destaca os seguintes pontos:

\footnotetext{
1) A mediação pode ser um sistema alternativo às sanções tradicionais; 2) Dentro de suas prioridades, estaria sem dúvida alguma a de melhorar a eficácia da justiça; 3) Confere assistência à vítima; 4) Afirma um direito penal orientado à reparação; 5) Possibilita a redução das penas privativas de liberdade; 7) Responsabiliza o delinquente por seus atos (AMARAL, 2005, p. $340)$.
}

Neste sentido a vítima terá maior atenção, pois a justiça poderá ter mais eficácia e o ofensor é convidado a fazer o processo de reflexão, reconhecendo o dano causado à vítima e também a comunidade participa do processo de restauração. Na Reparação do dano: “já não tem mais a exclusiva preocupação de atender à pretensão punitiva do Estado. Mas a satisfação dos danos sofridos pela vítima 'sempre que possível'”. (Amaral (2003, p. 326). A partir da Lei n. 9.099/95 (Juizados Especiais), “a vítima do suposto crime deixa de ser um espectador do processo penal para nele interagir como sujeito de direito de ver reparado o dano, destinandose uma etapa do procedimento para esse fim" (PRADO; CARVALHO, 2003, p.107).

A Lei 9.605/98 (Lei de Crimes Ambientais), mais do que a própria incriminação de conduta trata das três esferas de responsabilidade (civil, penal e administrativa), o juiz, ao homologar a composição civil ambiental, não só é ratificador da vontade das partes, pois o bem jurídico é equilíbrio ambiental. "Terceira via do Direito Penal”: Além da pena e da medida de segurança $\mathrm{O}$ autor terá a oportunidade de reconhecer o bem jurídico lesado que agrediu a vítima.

Na justiça clássica o autor tem uma atitude de defesa. Já na justiça restaurativa ele tem a oportunidade do autor não ser estigmatizado ou dissocializado. E a vítima se sente melhor atendido nas suas necessidades morais e materiais, evitando a segunda vitimização. Outro resultado é o enxugamento da máquina estatal e menos prejuízo para o estado nos casos de 
menor gravidade que a própria comunidade, mediante mediador poderá solucionar. (AMARAL, 2005, p. 344).

A reparação do dano na resolução do conflito que afetou a vítima e a comunidade, o autor ao reconhecer o dano, não teria a necessidade de recorrer a um processo civil. Rodrigues Delgado diz que a

\begin{abstract}
Reparação espontânea e voluntária em favor da vítima - e mesmo nos casos sem vítima individualizada, em que pode ser realizado um trabalho em favor da comunidade - contribui, sem dúvida, em primeiro lugar para a reafirmação do ordenamento jurídico, e em segundo lugar representa também um indício de que a pena preventiva de liberdade chega a ser desnecessária do ponto de vista da prevenção especial (AMARA, 2005, p. 354)8.
\end{abstract}

Amaral, analisa o pensamento de Rodríguez Delgado na necessidade de buscar mudanças no processo de reparação e que acredita que atinge o objetivo final, quando no diálogo entre as partes, se pode concluir que a reparação é uma forma mais humana e efetiva, não perdendo o caráter de ressocialização e sem sofre o estigmatismo tão forte em nossa sociedade que deseja ver o autor "pagar" pelo que fez. Assim, estamos desejando uma justiça vingativa ou retributiva, faltando a justiça restaurativa que pode ajudar o agressor a reconhecer os danos causado à vítima e se comprometer de fazer a reparação ou restauração.

Sobre a questão da terceira via como projeto de compensação autor-vítima surgiram na Alemanha e Áustria meados de 80, e elaboraram um Projeto Alternativo de Reforma do Código Penal alemão, de 1992, que trata da reparação do dano. Aparece ao lado da pena e da medida de segurança como terceira via, segundo a tese defendida por Claus Roxin (AMARAL, 2005, p. 358)9. Neste sentido, Luiz Gustavo Ribeiro e Diógenes Baleeiro Neto no artigo Medidas despenalizadoras, crise do Direito Penal e Meio ambiente. Eles destacam o pensamento da Roxin (1992, p.155) como:

\begin{abstract}
Adepto que é da chamada terceira via do Direito Penal, a reparação dos danos substituiria ou atenuaria a pena naqueles casos nos quais convenha, tão bem ou melhor, aos fins dela e às necessidades da vítima. Dessa forma, a inclusão no sistema penal, sancionador da indenização material e imaterial da vítima, significa que ele passa a se aproximar mais da realidade social, o que é de fundamental importância na tutela do meio ambiente natural e artificial (RIBEIRO; NETO, 2013, p. 17).
\end{abstract}

\footnotetext{
8 Ver o livro do Julio A. Rodrigues Delgado. La raparación como Sanción Jurídico-Penal: Nueva Doctrina Penal (breve compêndio de tese de doutoramento defendida na Universidade de Barcelona - 1998, p. 166.

9 Defende no grupo dos professores a reparação do dano de forma autônoma que mesmo sendo de ordem civil, mas na verdade está misturado com o penal.
} 
Isso vai além da indenização, pois pacifica as partes e deve ser feito antes do início do processo. Aplicabilidade universal do dano. Se não houve prejudicado individual, poderá beneficiar a comunidade. Voluntariedade se diferencia da terceira via de compensação obrigatória imposta pelo tribunal. No parágrafo $2^{\circ}$ o projeto dispõe que as prestações reparadoras terão em conta:

1) ressarcimento ao ofendido; 2) ressarcimento a terceiro, em particular, à companhia seguradora para o qual tenha sido transmitido o direito do ofendido; 3) Outras prestações materiais, como pagamento em dinheiro a entidade pública; 4) prestações de outra natureza ao ofendido, ou prestações imateriais, como, por exemplo, uma desculpa para uma conversa de reconciliação(entre as prestações imateriais podem ser incluídas as doações de sangue; 5) prestações de serviço, em especial, prestações de serviço em favor da comunidade, sendo que tais serviços poderão ser realizados também em favor do prejudicado (AMARAL, 2005, p. 361)

A reparação do dano como reação autônoma ao delito pode ser pensada como a: "restauração controlada da paz jurídica perturbada e a garantia da paz jurídica futura" (AMARAL, 2005, p.363). Esse caminho se faz pelo princípio da oportunidade de fazer a mediação, sem pretender de substituir o processo pena. Se pode ir buscando caminhos alternativos e trabalhando em conjunto em complementariedade do modelo de reparação, mediante a mediação e práticas restaurativas de justiça.

No processo de reparação de dano e de busca de despenalização ou descriminalização é preciso ver qual o melhor caminho para alcançar a solução. No estudo do Luiz Gustavo Ribeiro e Paulo Antônio Castro, citando um texto de Luiz Flávio Gomes e Silvio Maciel (2011, p. 303), analisam a questão referente ao PAC, pois ao se propor um termo de ajustamento de conduta de reparação do dano por crime ambiental significa que já houve um crime de dano ambiental, por exemplo. Assim, Maciel afirma que:

Sobre o assunto, poderíamos resenhar as seguintes correntes: (a) o ato de firmar o compromisso já significaria falta de justa causa para a persecução penal em curso; (b) o compromisso (TAC ou TCA) constituiria causa supralegal de exclusão da ilicitude; (c) o compromisso (TAC ou TCA) não teria nenhum reflexo penal se o compromissário desse continuidade aos atos criminosos (STJ, HC 61.199-BA, j. 04.10.2007, rel. Min. Jane Silva); (d) se a reparação do dano acontecesse antes do recebimento da denúncia, ocorreria uma causa de extinção da punibilidade (tal como no crime tributário); (e) o compromisso (TAC ou TCA) não tem nenhum reflexo penal (autonomia das instâncias). Para nós, o TAC ou TCA, enquanto em execução, impede a ação penal por falta de justa causa; depois de devidamente cumprido, torna a pena desnecessária (princípio da irrelevância da pena). (RIBEIRO; CASTRO, 2013, p. 10) 
Diante de todo este estudo podemos concluir que a sociedade vai evoluindo no sentido de buscar forma de atender as necessidades de superar a violência e os danos causados às pessoas, comunidades e ao meio ambiente. Estamos cansados das matanças e precisamos acordar e lutar por dias melhores de vivência dos seres humanos. Daí que a mera intenção de reparar o dano ambiental ou o esforço infrutífero não devam ser suficientes para a aplicação da atenuação da pena ou para sua isenção, embora não seja esta a orientação seguida pela lei ambiental. A construção de uma sociedade com normas, justiça social, Direitos Humanos de Meio Ambiente saudável faz da vida a plena alegria de acreditar nas práticas restaurativas.

\section{CONSIDERAÇÕES FINAIS}

Este trabalho da Justiça restaurativa com a utilização da mediação para resolução dos conflitos socioambientais nos tornou mais conhecedores de um amplo trabalho, mas ao mesmo tempo de uma satisfação de todas as partes resolução dos problemas. No caminho dos Direitos Humanos e o direito penal ambiental nos fez refletir a importância de ter mais que o domínio de saberes jurídicos ou códigos de leis e normas, pensando que apenas aplicando a lei teremos a solução do problema ou conflito. Faz falta uma vivência atenciosa de relações baseadas numa cultura de paz. São essas vivências que articulam discurso e prática que promovem relações pacíficas, solidárias e fraternas nos mais diversos grupos e espaços educativos, de forma a modificar de forma processual a cultura local marcada por conflitos não resolvidos e violentos, em espaços potenciais de cultura da paz. Mas temos o difícil papel de convencer os tribunais e o sistema penal brasileiro que utilizar apenas com resolução dos conflitos e danos a justiça retributiva ou aquela que castiga e pune. Este método tem tido sérios consequências na vida das pessoas e da sociedade. Como alcançar paz social, através de práticas restaurativas?

A justiça restaurativa procura sempre condenar o delito e restaurar as pessoas que são vítimas e os autores dos danos, Mas também a comunidade participa. Dessa forma faz-se necessário as práticas restaurativas que dê atenção à vítima, pois normalmente ela não participa do processo judicial no sistema penal. Esta forma de buscar a mediação dos conflitos proteger e reanimar a vítima, ajuda o agressor a reconhecer os danos causados para evitar a reincidência, promovendo a ressocialização de ambos. A Comunidade participa empoderando ambos, através do diálogo com ajuda do mediador (facilitador) encontrar a solução. 
Poderá ser usada de medidas despenalizadoras, mesmo no que tange aos crimes ambientais, comprometendo-se a reparar o dano, livrando-se, pois, de uma condenação privativa de liberdade. Este processo de mediação e práticas restaurativas se alcança, quando as partes reconhecem que houve um dano e que precisa ser reparado. No caso concreto estudado, por exemplo, nos faz refletir que houve um dano ambiental e social causado pela conduta da empresa de produção de Açaí. Faltava o reconhecimento de ambas as partes para que a comunidade como um todo conquiste dias melhores sem prejuízo ou destruição da natureza para as presentes e futuras gerações.

\section{REFERÊNCIAS}

ALMEIDA, Tânia. Justiça Restaurativa e Mediação de Conflitos - Mediare. Disponível em: www.mediare.com.br/08artigos_06justica_restaurativa.htm. Acesso em: 23 nov. 2014.

AMARAL, Cláudio do Prado. Despenalização pela reparação de danos: a terceira via. Leme: JH Mizuno, 2005.

ASSIS, Cleber Lizardo de. Direitos Humanos e a promoção da Cultura de Paz em espaço educativos formais e não-formais. In. BROCHADO, Mariá; ABREU, Décio; FREITAS, Mariá Brochado Décio AREU, Natália. Educação em Direitos Humanos, uma contribuição mineira. FMDH e UFMG, Belo Horizonte, 2014.

BOONEN, Petronella M. Justiça Restaurativa. In. Formação e Prática em Justiça Restaurativa. Escolas de Perdão e Reconciliação - ESPERE. São Paulo: CDHEP, Fundación para la Reconciliación. 2011. Ver Blog- justicarestaurativa-cdhep.blogspot.com 
BOTCHAROVA, Olga. Implementation of Track Two Diplomacy Developing a Modelo f Forgiveness. In HELMICK, Raymondo G. S. J; PETERSON, Rodney, Forginess and Reconciliation, Religionm Public Policy and Conflict Transformation, Philadelphia: The Templeton Foundation Press, 2001.

CARVALHO, Érika Mendes; CARVALHO, Gisele Mendes. A Reparação do dano ambiental como comportamento pós-delitivo. Manaus: XV Conpedi, Junho, 2006. Disponível em: http://www.conpedi.org.br/manaus/arquivos/anais/bh/erika_mendes_de_carvalho2.pdf. Acesso em: 26 nov. 2014.

\section{FUNDACIÓN PARA LA RECONCILIACIÓN. Diponível em:} Www.fundacionparalareconciliacion.org/

ESPERE - Escolas de Perdão e Reconciliação. Disponível em: http://cdhep.org.br/o-quefazemos/justica-restaurativa/espere-escola-de-perdao-e-reconciliacao. Acesso em: 24 nov. 2014.

GOMES, Luiz Flávio; MACIEL, Silvio. Crimes ambientais: comentários à Lei 9.605/98. São Paulo: Revista dos Tribunais, 2011.

LEDERACH, John Paul. The Little Book of Conflict Transformation. Clear aeritulation of the guiding principles by a pioneer in the field, Interrcourse, good Book, 1997.

MELLO, Eduardo Resende et al. Justiça Restaurativa e comunitária em São Caetano do Sul: aprendendo com os conflitos a respeitar e promover a cidadania. Rio de Janeiro: Cecip, 2008.

PAIM, Vania. Neoconstitucionalismo e justiça restaurativa no Brasil. Disponível em: http://portal.estacio.br/media/4120821/vania\%2520paim.pdf. Acesso em: 21 nov. 2014.

PENIDO, Egberto de Almeida. Infãncia e Juventude e a Justiça Restaurativa. Disponível em: PENIDOwww.tjsp.jus.br/EGov/InfanciaJuventude/.../JusticaRestaurativa. Acesso em: 23 nov. 2014. 
PINTO, Renato Sócrates Gomes. Tradução do documento arquivado no site . Acesso em 18 de agosto de 2008.

PNUD/MINISTÉRIO DA JUSTIÇA. Justiça Restaurativa para resolução de conflitos. Disponível em: www.cidadessustentaveis.org.br/.../justica-restaurativa-para-resolucao-deconflitos, 2013.Acesso em: 23 nov. 2014.

PRUDENTE, Neemias Moretti. Justiça Restaurativa: Marco teórico, experiências brasileiras, Propostas e Direitos Humanos. Goiânia: Bookess e Kindle, 2013. Disponível em: http://justicarestaurativaemdebate.blogspot.com/2012/03/projeto-do-curso-espere-e-praticas. Acesso em: 24 nov. 2014.

RIBEIRO, Luiz Gustavo Gonçalves. BALEEIRO NETO, Diógenes. Medidas despenalizadoras e proteção penal do ambiente. In: SOUZA, Maria Cláudia da Silva Antunes de; FIORILLO; Celso Antônio Pacheco; YOSHIDA, Consuelo Yatsuda Moromizato (Org.). Direito Ambiental II. Florianópolis: FUNJAB, 2014, p. 442-462.

RIBEIRO, Luiz Gustavo Gonçalves; CASTRO, Paulo Antônio Grahl Monteiro. Reparação do dano nos crimes ambientais: Terceira via como excesso de permissividade ou avanço a um direito Penal de intervenção mínima?

SILVA, Karina Duarte Rocha. Justiça Restaurativa e sua Aplicação no Brasil. Brasília, 2007. Disponível em: http://www.idcb.org.br/documentos/Ebook_justice.pdf. Acesso em: 23 nov. 2014.

YAZBEK, Vania Curi et al. Justiça Restaurativa como um método de resolução de conflitos. Disponível em: file.fde.sp.gov.br/portalfde/arquivo/mediacao/JusticaRestaura.pdf. Acesso em: 23 nov. 2014. Ver também sobre Justiça em círculo. Equipe de capacitação em Justiça Restaurativa. Disponível em: www.mediativa.org.br.Acesso em: 23 nov. 2014. 